\title{
Revisiting the winners and the losers a decade after coral bleaching
}

\author{
R. van Woesik ${ }^{1, *}$, K. Sakai ${ }^{2}$, A. Ganase ${ }^{1}$, Y. Loya ${ }^{3}$ \\ ${ }^{1}$ Department of Biological Sciences, Florida Institute of Technology, Melbourne, Florida 32901, USA \\ ${ }^{2}$ Sesoko Station, Tropical Biosphere Research Center, University of the Ryukyus, Motobu, 905-0227 Okinawa, Japan \\ ${ }^{3}$ Department of Zoology, Tel Aviv University, Tel Aviv 69978, Israel
}

\begin{abstract}
Over the past 3 decades, thermal stress events have damaged corals globally. Few studies, however, have tracked the recovery process or assessed whether winners in the short term are also winners in the long term. In the present study, we repeatedly sampled a coral assemblage over a 14 yr period, from 1997 to 2010, through 2 thermal stress events (in 1998 and 2001). Our goal was to examine the consistency of short-term winner and loser outcomes over the recovery period. Although species richness had recovered after $10 \mathrm{yr}$, the reef composition had changed, and few pocilloporids were to be found. The short-term winners were the thermally tolerant encrusting and massive coral morphologies (Porites and faviids) and Acropora colonies $<5 \mathrm{~cm}$ in diameter. Long-term winners were revealed as (1) thermally tolerant, locally persistent colonies, (2) remnant survivors that rapidly regrew, and (3) regionally persistent colonies that recruited.
\end{abstract}

KEY WORDS: Coral bleaching $\cdot$ Climate adaptation $\cdot$ Temperature $\cdot$ Reefs $\cdot$ Recovery

\section{INTRODUCTION}

Reef corals have recently experienced unprecedented thermal stress events (Glynn 1984, 1988, 1991, HoeghGuldberg 1999, Aronson et al. 2000, IPCC 2007). In many localities, extreme thermal stress has led to extensive coral bleaching, mortality and dramatic shifts in coral community structure (Marshall \& Baird 2000, Loya et al. 2001, McClanahan 2004). Under such circumstances, corals with branched and corymbose growth forms, such as Acropora, Pocillopora, Stylophora, Seriatopora and branched Porites spp., are generally more susceptible to thermal stress than corals with massive and encrusting growth forms, such as massive Porites and faviids (Loya et al. 2001). Such findings are consistent throughout the Indo-Pacific region (Brown \& Suharsono 1990, Marshall \& Baird 2000, McClanahan 2004, McClanahan et al. 2007a,b). Thermal sensitivity of corals has been associated with high metabolic rates (Gates \& Edmunds 1999), thin coral colony tissue thickness (Loya et al. 2001), low mass-transfer rates (Naka- mura \& van Woesik 2001), low concentrations of green fluorescent proteins (Bou-Abdallah et al. 2006), high light-absorbing capacities (Fabricius 2006) and intolerant symbionts (Baker 2001). Although thermal tolerance is clearly attributed to the properties of both the host coral and the resident symbionts (Baird et al. 2009), acclimation and adaptation to the local environment also plays a role in thermal susceptibility (McClanahan \& Maina 2003, Smith-Keune \& van Oppen 2006).

Over the next century, the climate is predicted to drive water temperatures to levels above those that have been experienced by coral reefs for over $400000 \mathrm{yr}$ (Hoegh-Guldberg et al. 2007), consequently increasing the risk of mass-bleaching events (Glynn 1993, HoeghGuldberg 1999, Donner et al. 2005, Hoegh-Guldberg et al. 2007). The oceans, however, are not homogenous and thermal stress events are not consistent over space and time (Wilkinson et al. 1999, McClanahan et al. $2007 a, b)$. In the Pacific Ocean, some localities have historically experienced frequent thermal anomalies (every 5 to 6 yr), whereas other localities have experi- 
enced anomalous temperatures only every 50 to $60 \mathrm{yr}$ (Thompson \& van Woesik 2009). For example, the southern islands of Japan, the Great Barrier Reef and Micronesia all historically show low-frequency return periods ( $50 \mathrm{yr})$, whereas the Galapagos Islands and Kiribati historically show high-frequency return periods ( 5 yr) (Thompson \& van Woesik 2009). Not only are contemporary worldwide patterns in thermal anomalies similar to those in the past, but the localities that have shown high-frequency return periods in the past few centuries have also recently experienced the most severe thermal stress (Thompson \& van Woesik 2009). If these patterns persist into the near future, then some localities will receive both more intensive and more frequent thermal stress than other localities.

Short-term studies suggest that some coral species are destined to become the 'winners', whereas others are destined to become the 'losers' (Loya et al. 2001). However, simply tolerating local thermal stress is not the only viable life-history strategy to persist through time. Ephemeral assemblages that are usually susceptible to local stress also survive regionally by being highly fecund and growing quickly (MacArthur \& Wilson 1967, Loya 1976, Gates \& Edmunds 1999). Regional persistence also depends on (1) the local survival of small fragments, which have an inherent capacity for regrowth, (2) whether corals on neighboring reefs survived through the thermal stress, (3) whether those neighboring corals have the capacity to supply recruits, (4) the survival of recruits from neighboring reefs, and (5) the return frequency and intensity of the thermal stresses.

Few studies have examined the longterm recovery of coral assemblages following thermal stress. Here, we ask whether a winning species in the short term is also a winner in the long term. Previously we reported on the shortterm effects of a severe thermal stress $\left(\sim 3^{\circ} \mathrm{C}\right.$ above the seasonal average $)$ on the coral populations of Sesoko Island (Okinawa) in 1998 (Loya et al. 2001), and a moderate thermal stress $\left(1.8^{\circ} \mathrm{C}\right.$ above the seasonal average water temperature) on islands $30 \mathrm{~km}$ southwest of Okinawa in 1998 (Roth et al. 2010). The present study tracked the coral populations in the lee of Sesoko Island, Japan, from 1997 to 2010, including nearly a decade of recovery during which the sea surface temperatures did not exceed seasonal averages (Fig. 1). Our primary objective was to assess the existence of any consistencies between short-term and long-term winners and losers.

\section{MATERIALS AND METHODS}

This study was undertaken on the southeastern reef of Sesoko Island, at the Sesoko Station of the Tropical Biosphere Research Center (University of the Ryukyus), Okinawa, Japan $\left(26^{\circ} 38^{\prime} \mathrm{N}, 127^{\circ} 52^{\prime} \mathrm{E}\right)$. The reef flat is approximately $100 \mathrm{~m}$ wide and $2 \mathrm{~m}$ deep at high tide. The study site is a protected zone, regulated by the research station, and comprises an area of ca. $2500 \mathrm{~m}^{2}$, as described and illustrated in Sakai \& Yamazato (1984). Each year, 25 to 30 random $1 \mathrm{~m}^{2}$ quadrats were surveyed using SCUBA. Sampling was carried out in 1997, 1999, 2000, 2001, 2004, 2007 and 2010. Each hard (stony) coral colony was identified to species and each soft coral colony was identified to genus. Only corals with their centers in the quadrats were measured (Zvuloni et al. 2008). For each colony in 1997 and 1999, colony length, width and height (to the nearest $\mathrm{mm}$ ) was recorded. Projected surface area $\left(A_{\mathrm{PS}} \mathrm{cm}^{2}\right)$ of each colony was also estimated assuming an oval (i.e. elliptical) colony shape, using the equation $A_{\mathrm{PS}}=(L / 2)(W / 2)$, where $L$ is the length axis of a colony and $W$ is the width measured perpendicular to the length axis (mm). From 2000 onwards, we only measured the diameter of each colony. The projected surface area of each colony was estimated by assuming that the colonies were approximately circular, using the formula $\pi r^{2}$. We found little difference $( \pm 0.3 \%)$ in the projected surface area using the elliptical and circle formulae and therefore chose the more rapid field approach, by simply measuring each colony's diameter.

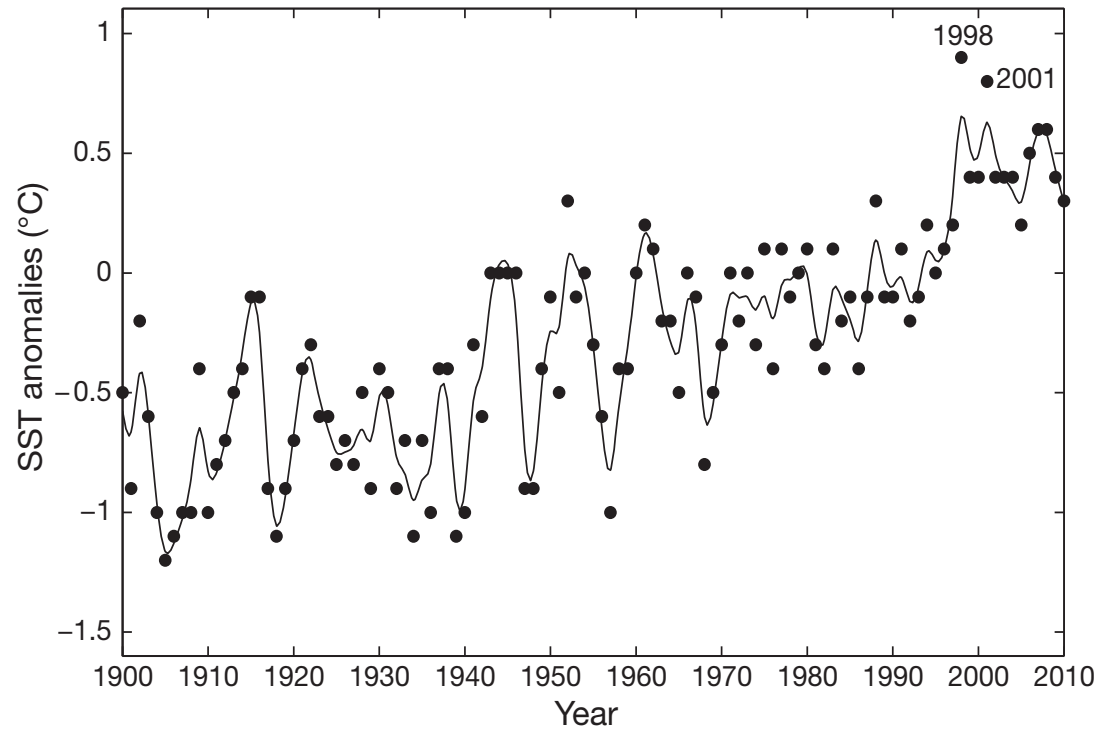

Fig. 1. One hundred and ten years of sea surface temperature (SST) anomalies for the South East China Sea region, where Sesoko Island is located. A smoothing spline (adj. $\mathrm{R}^{2}=0.8324$ ) was fitted through the annual data (residual mean squared error $=0.1934)$; data were derived from the Japan Meteorological Agency (www.data.kishou.go.jp/db/nagasaki/nagasaki_warm/areaB_SST.txt) 
A Wilcoxon matched-pair signed ranked test was used to determine whether there were discernable differences in absolute and relative percentage cover of each coral species through time. We were particularly interested in whether short-term effects were similar to long-term effects, and whether, and to what extent, the coral communities changed through time. In our 2001 publication, for each given species we summed the percentages across quadrats (Loya et al. 2001, their Table 1). In the present study, we calculated the relative contribution of each species in each quadrat relative to the contribution of that species across quadrats for each time period. More specifically, we compared the relative abundance and relative cover of each coral species in the following pairs of years (1) 1997 vs. 1999, (2) 1997 vs. 2000, (3) 1997 vs. 2010 and (4) 1999 vs. 2010. We were particularly interested in determining which species were short-term and long-term winners and losers. Therefore, we maintained the alpha value at 0.05 for each test in order to maintain power to detect meaningful ecological change through time (Rothman 1990).

We took a Bayesian approach (Gelman et al. 2003) to estimate the mean growth rates of corymbose Acropora species (which were mainly represented by $A$. gemmifera, A. digitifera and A. nasuta). We also compared the growth rates of corymbose Acropora at Sesoko Island with its growth rates at the same depth from reefs in the central Great Barrier Reef (Done et al. 2010). In both cases, we used a logistic growth model to predict the change in the mean colony diameter through time $\left(d_{t}\right)$ using the equation:

$$
d_{t}=L_{\mathrm{fin}} /\left(1+a \exp ^{-b t}\right)
$$

where $L_{\text {fin }}$ is the diameter of corymbose Acropora colonies, which rarely exceeds $40 \mathrm{~cm}$, and $a$ and $b$ are the fitted parameters of the logistic model over time $(t)$. A normal likelihood function, $\theta$, and normal priors for $a$ and $b$, with a gamma prior of the precision, were used to calculate the posterior probabilities, $\mathrm{p}(\theta \mid \mathrm{y})$, for colony growth data $d_{t}$. To obtain a useful posterior probability of growth rates, we used Markov chain Monte Carlo simulations employing Gibbs sampling. This method also determined the $95 \%$ credible intervals of the predicted growth rate parameters $a$ and $b$. All models were implemented using WinBugs 1.4 (MRC Biostatistics Unit, available at www.mrc-bsu.cam.ac.uk/bugs/).

\section{RESULTS}

There was an immediate decrease in branching pocilloporids, branching Porites and all Acropora species $>5 \mathrm{~cm}$ in diameter following the 1998 thermal stress event. By 2000, there was some hard coral recovery, evidenced by an increase in colony density and growth of survivors (Figs. $2 \& 3$ ). However, the thermal
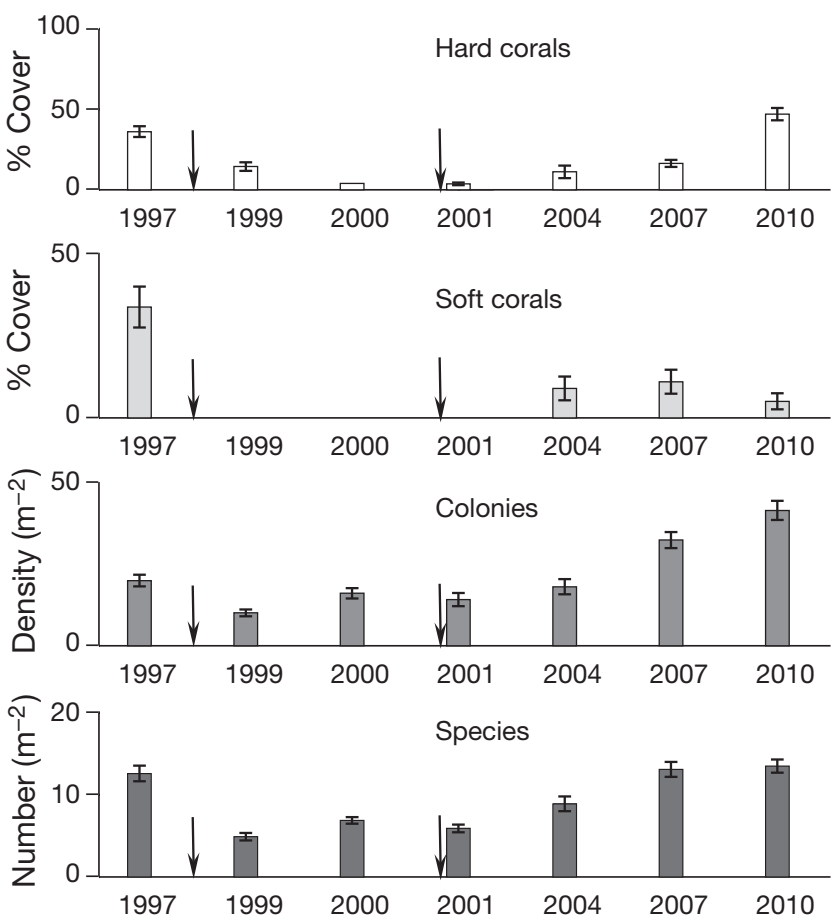

Fig. 2. Changes in percentage hard coral cover, percentage soft coral cover, density of hard coral colonies $\left(\mathrm{m}^{-2}\right)$ and coral species richness from 1997 to 2010 at Sesoko Island, Okinawa, Japan. Data are means \pm SE. The 1998 and the 2001 thermal stress events are indicated by arrows
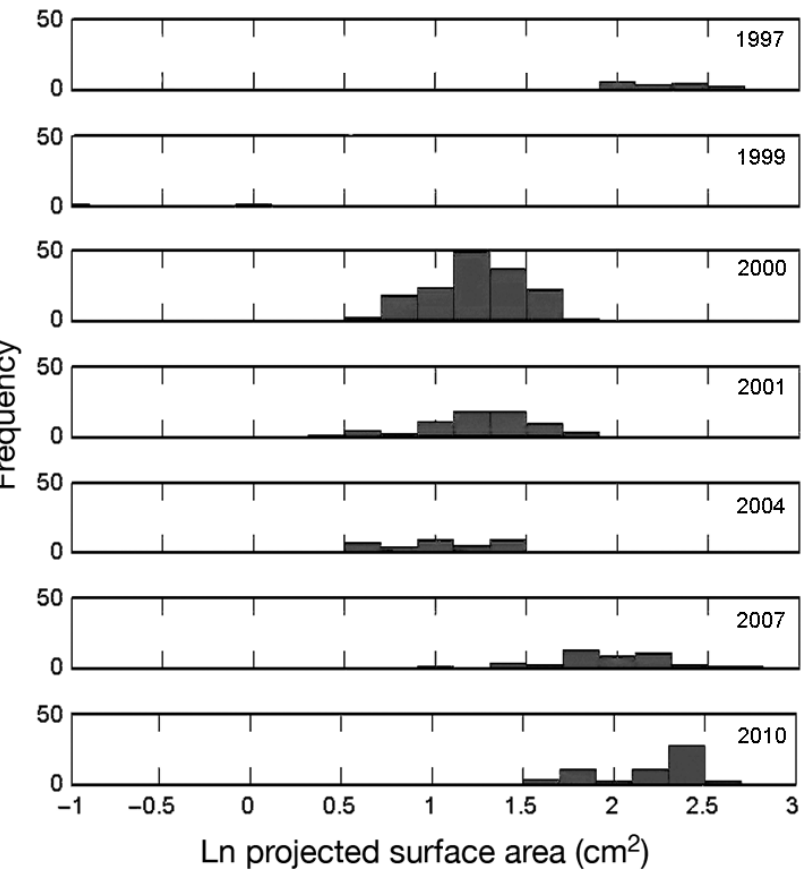

Fig. 3. $\log _{\mathrm{e}}$-transformed size-frequency distribution of the projected surface area of corymbose Acropora colonies, from 1997 to 2010, at Sesoko Island, Okinawa, Japan 
Table 1. Structural shifts in the coral community from 1997 to 2010, with respect to relative abundance and relative percentage coral cover (both measures of mean \pm SE percent contribution to living population), at Sesoko Island, Okinawa. Winners were coral species that increase in their relative contribution to the total living cover, and losers were coral species that decreased in their relative contribution. ns: not significant; ${ }^{*} \mathrm{p}<0.05 ;{ }^{* *} \mathrm{p}<0.01 ;{ }^{* * *} \mathrm{p}<0.001$. Absence indicated by $(-)$

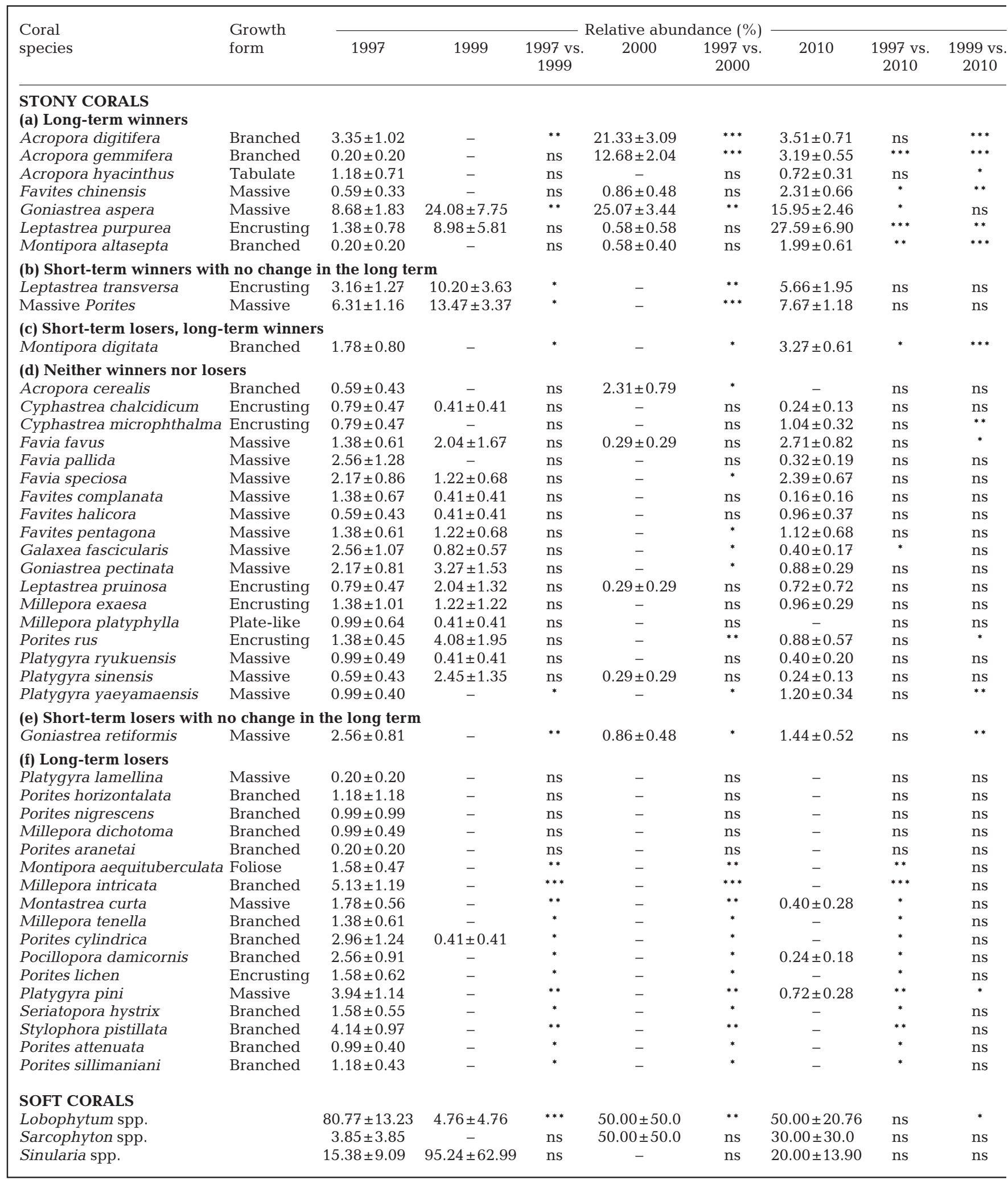


Table 1 (continued)

\begin{tabular}{|c|c|c|c|c|c|c|c|}
\hline 1997 & 1999 & $\begin{array}{c}1997 \text { vs. } \\
1999\end{array}$ & 2000 & $\begin{array}{c}1997 \text { vs. } \\
2000\end{array}$ & 2010 & $\begin{array}{c}1997 \text { vs. } \\
2010\end{array}$ & $\begin{array}{c}1999 \text { vs. } \\
2010\end{array}$ \\
\hline $2.31 \pm 0.67$ & - & ns & $17.47 \pm 3.16$ & *** & $7.62 \pm 2.12$ & ${ }^{*}$ & $* * *$ \\
\hline $0.12 \pm 0.12$ & - & ns & $8.86 \pm 1.78$ & $* * *$ & $9.92 \pm 2.07$ & $* * *$ & $* * *$ \\
\hline $0.83 \pm 0.49$ & - & ns & - & ns & $4.62 \pm 2.57$ & * & $*$ \\
\hline $0.83 \pm 0.49$ & - & $\mathrm{ns}$ & $12.33 \pm 11.62$ & ns & $1.73 \pm 0.65$ & ns & $* *$ \\
\hline $3.54 \pm 0.73$ & $0.52 \pm 0.28$ & $* * *$ & $27.07 \pm 6.51$ & $* * *$ & $1.93 \pm 0.30$ & ns & $* * *$ \\
\hline $1.00 \pm 0.56$ & $0.05 \pm 0.03$ & ns & $0.41 \pm 0.41$ & ns & $4.45 \pm 1.28$ & ${ }^{* *}$ & $* * *$ \\
\hline $0.23 \pm 0.23$ & - & ns & $0.25 \pm 0.18$ & ns & $3.95 \pm 1.21$ & $* *$ & $* * *$ \\
\hline $3.58 \pm 1.50$ & $9.55 \pm 8.52$ & ns & - & ${ }^{*}$ & $6.15 \pm 2.44$ & ns & $\mathrm{ns}$ \\
\hline $22.71 \pm 6.35$ & $44.84 \pm 17.25$ & ns & - & $* * *$ & $18.62 \pm 5.11$ & ns & ns \\
\hline $1.14 \pm 0.50$ & - & * & - & $*$ & $7.18 \pm 2.01$ & $* *$ & $* * *$ \\
\hline $0.13 \pm 0.12$ & - & ns & $1.39 \pm 0.58$ & * & - & $\mathrm{ns}$ & $\mathrm{ns}$ \\
\hline $3.05 \pm 2.76$ & $0.02 \pm 0.02$ & ns & - & ns & $0.73 \pm 0.58$ & ns & ns \\
\hline $0.34 \pm 0.24$ & - & ns & - & ns & $1.13 \pm 0.39$ & ns & $* *$ \\
\hline $0.92 \pm 0.43$ & $0.02 \pm 0.02$ & $*$ & $0.21 \pm 0.21$ & ns & $0.67 \pm 0.21$ & ns & $* * *$ \\
\hline $1.55 \pm 0.79$ & - & ns & - & $\mathrm{ns}$ & $0.11 \pm 0.06$ & $\mathrm{~ns}$ & ns \\
\hline $2.17 \pm 0.93$ & $0.31 \pm 0.26$ & ns & - & ${ }^{*}$ & $1.18 \pm 0.52$ & $\mathrm{~ns}$ & ${ }^{*}$ \\
\hline $1.20 \pm 0.48$ & $0.02 \pm 0.02$ & ns & - & $\mathrm{ns}$ & $0 . .03 \pm 0.03$ & $\mathrm{~ns}$ & $\mathrm{~ns}$ \\
\hline $0.56 \pm 0.40$ & $8.53 \pm 8.53$ & ns & - & $\mathrm{ns}$ & $0.26 \pm 0.09$ & $\mathrm{~ns}$ & $\mathrm{~ns}$ \\
\hline $0.85 \pm 0.37$ & $0.21 \pm 0.21$ & ns & - & ${ }^{*}$ & $0.25 \pm 0.15$ & ${ }^{*}$ & ns \\
\hline $0.90 \pm 0.50$ & $0.01 \pm 0.01$ & $*$ & - & $*$ & $0.43 \pm 0.26$ & ns & ${ }^{*}$ \\
\hline $1.22 \pm 0.48$ & $0.06 \pm 0.04$ & $*$ & - & $*$ & $0.63 \pm 0.21$ & $\mathrm{~ns}$ & $* *$ \\
\hline $0.58 \pm 0.32$ & $0.09 \pm 0.09$ & $\mathrm{~ns}$ & $0.07 \pm 0.07$ & ns & $0.27 \pm 0.27$ & $\mathrm{~ns}$ & ns \\
\hline $0.61 \pm 0.42$ & $0.01 \pm 0.01$ & ns & - & ns & $0.57 \pm 0.23$ & ns & $* *$ \\
\hline $1.42 \pm 0.84$ & - & ns & - & ns & - & ns & $\mathrm{ns}$ \\
\hline $0.90 \pm 0.41$ & $2.05 \pm 1.65$ & ns & - & $*$ & $0.39 \pm 0.29$ & $\mathrm{~ns}$ & $\mathrm{~ns}$ \\
\hline $0.90 \pm 0.43$ & - & ns & - & $\mathrm{ns}$ & $0.10 \pm 0.05$ & $\mathrm{~ns}$ & $\mathrm{~ns}$ \\
\hline $0.49 \pm 0.34$ & - & ns & $0.13 \pm 0.08$ & ns & $0.10 \pm 0.06$ & $\mathrm{~ns}$ & ns \\
\hline $1.18 \pm 0.50$ & - & $*$ & - & $*$ & $0.23 \pm 0.09$ & ns & $* *$ \\
\hline $1.34 \pm 0.51$ & - & * & $2.32 \pm 1.59$ & ns & $0.77 \pm 0.24$ & ns & $* *$ \\
\hline $0.21 \pm 0.21$ & - & ns & - & $\mathrm{ns}$ & - & ns & $\mathrm{ns}$ \\
\hline $1.33 \pm 1.33$ & - & ns & - & ns & - & ns & $\mathrm{ns}$ \\
\hline $1.55 \pm 1.55$ & - & ns & - & ns & - & ns & ns \\
\hline $2.36 \pm 1.28$ & - & ns & - & ns & - & ns & ns \\
\hline $1.33 \pm 1.33$ & - & $\mathrm{ns}$ & - & $\mathrm{ns}$ & - & $\mathrm{ns}$ & $\mathrm{ns}$ \\
\hline $1.73 \pm 0.60$ & - & ** & - & ${ }^{*}$ & - & ${ }^{*}$ & $\mathrm{~ns}$ \\
\hline $6.08 \pm 2.01$ & - & $* * *$ & - & $* *$ & - & $* * *$ & $\mathrm{~ns}$ \\
\hline $1.19 \pm 0.38$ & - & ${ }^{*}$ & - & * & $0.04 \pm 0.03$ & * & $\mathrm{ns}$ \\
\hline $0.94 \pm 0.41$ & - & * & - & * & - & * & ns \\
\hline $1.90 \pm 0.85$ & - & * & - & * & - & * & ns \\
\hline $1.44 \pm 0.49$ & - & $*$ & - & * & $0.01 \pm 0.01$ & * & $\mathrm{ns}$ \\
\hline $1.02 \pm 0.50$ & - & * & - & * & - & * & $\mathrm{ns}$ \\
\hline $3.18 \pm 0.87$ & - & ** & - & *** & $0.20 \pm 0.09$ & ** & ${ }^{*}$ \\
\hline $0.61 \pm 0.21$ & - & ${ }^{*}$ & - & * & - & * & $\mathrm{ns}$ \\
\hline $1.93 \pm 0.45$ & - & $* *$ & - & $* *$ & - & $* *$ & $\mathrm{~ns}$ \\
\hline $2.30 \pm 1.26$ & - & $*$ & - & $*$ & - & * & ns \\
\hline $2.06 \pm 0.85$ & - & $*$ & - & $*$ & - & $*$ & ns \\
\hline $91.08 \pm 19.25$ & $23.78 \pm 23.78$ & $* *$ & $92.16 \pm 92.16$ & $* *$ & $89.14 \pm 49.61$ & ns & ${ }^{*}$ \\
\hline $1.40 \pm 1.40$ & - & ns & $7.84 \pm 7.84$ & ns & $2.14 \pm 2.14$ & ns & ns \\
\hline $7.53 \pm 4.49$ & $76.22 \pm 43.69$ & ns & - & $\mathrm{ns}$ & $8.72 \pm 6.06$ & ns & ns \\
\hline
\end{tabular}

stress events in 2001 caused another decrease in coral cover (Figs. 2 \& 3). Hard coral cover increased from $3 \%$ in 2001 to $47 \%$ in 2010, whereas soft coral cover never exceeded $10 \%$ after 1998 (Fig. 2). Change in coral colony densities followed the same trend as coral cover, increasing steadily through time (Fig. 2). By 2007, species richness had recovered to $\sim 13$ species $\mathrm{m}^{-2}$, which was similar to species richness in 1997, although the species composition had undergone change (Table 1).

The most common corals on Sesoko Reef in 2010, in terms of both relative percentage cover and relative abundance, were Goniastrea aspera, massive Porites, Leptastrea purpurea, L. transversa, Montipora digitata, Acropora gemmifera, A. digitifera and Favia favus. These coral populations, however, took different trajectories over the 14 yr study period. The first 2 species were thermally tolerant and increased in relative abundance through time (Table 1a). Leptastrea purpurea increased in relative abundance through the thermal stress events and continued to increase (Table 1a), whereas L. transversa increased in relative abundance through the thermal stress and remained constant thereafter (Table 1b). Massive Porites were short-term winners, but did not increase overall over time (Table 1b). The branched Montipora species, especially $M$. digitata, declined in 1998 to only a few remnant survivors, but had recovered by 2010 (Table 1c). Thirteen faviids were neither winners nor losers through time (Table 1d). Indeed, species that did not change through time were mainly the massive colonies. Sinularia spp. were the most resistant soft corals to the initial thermal stress, and increased in relative abundance and cover in 1999. By 2010, Sinularia spp. had returned to the same relative cover and abundance as in 1997. In contrast, Lobophytum spp. and Sarcophyton spp. initially decreased in 1998, but had returned to similar relative cover and abundance by 2010 (Table 1). 
Only one species (Goniastrea retiformis) was a short-term loser but showed no change in the long term (Table 1e). Twelve hard coral species showed a significant decrease in both relative percentage cover and abundance through time (Table 1f); 5 species (Platygyra lamellina, Porites horizontalata, Porites nigrescens, Porites aranetai and Millepora dichotoma), uncommon in 1997, did not show a significant decline through time but were no longer recorded in the Sesoko Island area in subsequent surveys (Type II error). Most of the species that were losers in 1999 remained losers throughout the $14 \mathrm{yr}$ study, particularly the pocilloporids (Stylophora spp., Pocillopora spp., and Seriatopora spp.). Twelve of the 17 long-term losers showed no recovery (e.g. Seriatopora hystrix and Stylophora pistillata), and Pocillopora colonies were still uncommon in 2010. Branching Porites suffered a similar fate, and were also not found at the study site in 2010 (Table 1f).

Although most Acropora colonies $>5 \mathrm{~cm}$ died in 1998, the corymbose Acropora populations had recovered slightly by 2000, and declined again in 2001 during the thermal stress event. The size-frequency distribution of corymbose Acropora species changed from a log-normal distribution in 1997 to a right-skewed distribution in 1999 and back to a log-normal distribution in 2001. Following the second thermal stress, there was a steady increase in colony size from 2004 to 2010 (Fig. 3). The mean growth rate of the corymbose Acropora colonies, after the 2001 thermal stress, followed an S-shaped logistic function. Mean growth was slow in the first few years after recruitment, at just over $1 \mathrm{~cm} \mathrm{yr}^{-1}$. Growth rates increased to $\sim 3-4 \mathrm{~cm} \mathrm{yr}^{-1}$ at $7 \mathrm{yr}$, and then decreased thereafter (Fig. 4). The growth rates of corymbose Acropora on the Great Barrier Reef followed a remarkably similar pattern to those of the corymbose Acropora at Sesoko Island.

\section{DISCUSSION}

\section{Short-term winners}

Most of the massive Porites ( $P$. lutea and P. lobata) and the faviids survived the 1998 thermal stress, including Leptastrea purpurea, L. transversa, Goniastrea aspera and Favia favus (Table 1). However, the perennial question remains: What biological or physical traits allow some corals to resist thermal stress, whereas other corals bleach and die (van Woesik et al. 2004)? Bleached corals that rely exclusively on metabolites from symbionts are likely to die rapidly when their nutrient source is removed, whereas feeding on plankton, when depleted of symbionts, will facilitate colony survival (Grottoli et al. 2006). Similarly, thin-tissued corals have limited resources and may die rapidly after bleaching (Loya et al. 2001).

Nevertheless, the physical properties of corals (including shape, size and height), which influence gas and metabolite exchange across boundary layers, in turn affect thermal susceptibility (Nakamura \& van Woesik 2001). However, the interactions between 
such mass transfer and irradiance are not straightforward. Because the tips of coral branches receive the highest irradiance, thus increasing photoinhibition (van Woesik \& Koksal 2006), they also receive the highest flow (i.e. mass transfer), which sequesters thermal stress (Nakamura et al. 2003). Our previous study also revealed that Acropora colonies $>5 \mathrm{~cm}$ were not resistant to thermal stress on a local scale, whereas juveniles $<5 \mathrm{~cm}$ did survive such thermal stress (Loya et al. 2001). Survival of these small Acropora colonies in 1998 had become obvious by 2000, when $A$. gemmifera and A. digitifera substantially contributed to relative coral abundance (Table 1) only to again suffer a decline in 2001, when those small colonies had increased in size. Theoretically, small colonies have higher mass transfer rates than large colonies (Nakamura \& van Woesik 2001), but Acropora recruits also have conspicuously higher concentrations of green fluorescent protein than large colonies (Papina et al. 2002), which have strong antioxidant properties (Bou-Abdallah et al. 2006). Such complexities exemplify the need for controlled experiments that partition these variables, enabling more precise predictions of differential survival based on biological and physical traits.

\section{Short-term losers but long-term winners}

In 1999, only a few Montipora digitata and M. altasepta were recorded in our quadrats. We noticed (K. Sakai pers. obs.) that these remnant branches grew rapidly and fragmented each typhoon season. By 2010, both branched species occupied a considerable proportion of the substrate (Table 1). It thus seems that the recovery of branched Montipora was largely by means of remnant survival and rapid regrowth rather than recruitment.

The gradual recovery of some species of Acropora suggests that the ecosystem was still able to absorb the thermal stressors without undergoing change to a less desirable state (Holling 1973, Scheffer \& Carpenter 2003). There is a high level of genetic connectivity between the Acropora populations in the Kerama Islands, $30 \mathrm{~km}$ southwest of Okinawa, and Sesoko Island (Nishikawa et al. 2003, Nakajima et al. 2010). Moreover, neighboring reefs in the Kerama Islands continued to support Acropora colonies throughout the thermal stress events (Roth et al. 2010). Therefore, it is highly likely that the Kerama Islands facilitated Acropora recovery on Sesoko Island by supplying recruits. Similarly, Acropora populations had fully recovered $7 \mathrm{yr}$ after an extreme thermal-stress event in Palau (Golbuu et al. 2007); and in the Arabian Gulf, Riegl \& Purkis (2009) showed that Acropora assem- blages could recover from thermal-stress cycles occurring every $15 \mathrm{yr}$.

Acropora recovery is illustrated in Fig. 4, which offers a useful baseline for researchers examining disturbance and recovery periods. If corymbose Acropora populations at specific localities do not closely reflect these recovery trajectories, then the locality of interest may be suffering from stress. A slowing of the rates may also represent the approach of a critical threshold indicating a less desirable state, beyond which recovery is more difficult (van Nes \& Scheffer 2007). Nonetheless, predicting population recovery is complex. Recovery also depends on a number of variables, including the spatial scale of a species' distribution, its fecundity, how the neighboring sites fare through stress events and their capacity to supply recruits, and the intensity and frequency of the disturbance (Dayton 1971, Sousa 1979).

Adult Acropora are extremely fecund (Wallace 1985), grow quickly and are susceptible to most physical anomalies (Loya et al. 2001). Such life-history traits most often induce an ephemeral existence locally, but allow regional persistence. The rate and degree of Acropora recovery also depend on the density of nearby adult colonies (Hughes et al. 2000). On the Great Barrier Reef, for example, Done et al. (2010) contended that the dense aggregation of reefs, well connected oceanographically to a source of adult Acropora populations, facilitated rapid Acropora recovery following Acanthaster planci disturbance. The genus Acropora, however, is comprised of over 100 species. By 2010, there was a proliferation of Acropora gemmifera and $A$. digitifera at Sesoko Island (Table 1, Fig. 4), whereas other species, such as A. hyacinthus and A. cerealis, were less common in 2010 (Table 1).

If Acropora populations are subjected to more intensive and frequent thermal anomalies, will the IndoPacific coral reefs eventually become devoid of Acropora? Côté \& Darling (2010) recently suggested that the reefs with the best chance of survival in the face of climate change will be the resistant reefs without Acropora. They also suggested that Acropora and Montipora will be replaced by Porites and Platygyra in the Indo-Pacific. Porites, in particular P. lobata, P. lutea, $P$. rus and $P$. cylindrica, which are the main reef-building Porites of the Indo-Pacific, are all leeward species. Platygyra is naturally uncommon (Table 1). Consequently, Porites and Platygyra might not necessarily replace Acropora in the near future, because they are not generally constrained by Acropora, they simply occupy different habitats (van Woesik \& Done 1997) and are constrained by different environmental variables. What we may witness in the near future is an increase in free space (i.e. carbonate covered in turf algae) on reefs through time. 


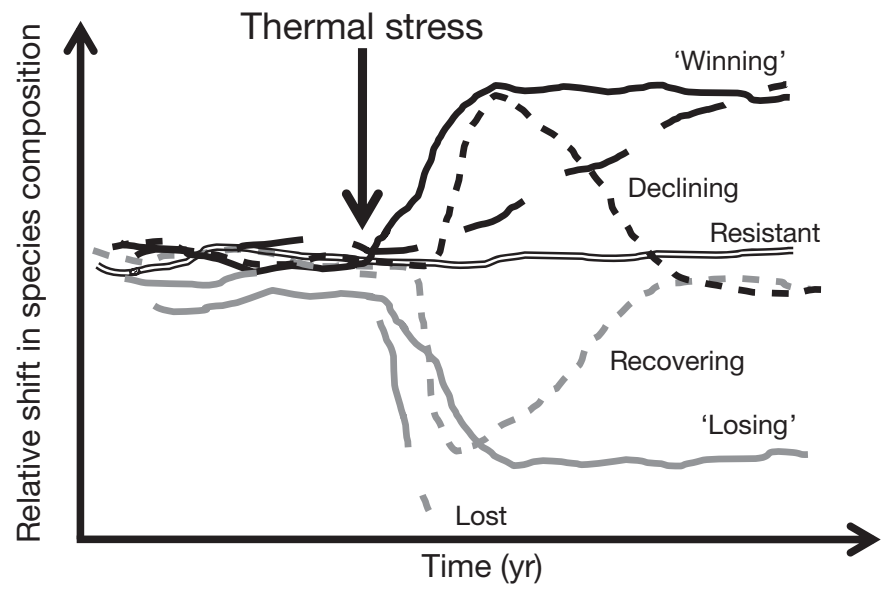

Fig. 5. Winners and losers from 1997 to 2010. The thermal stress event was followed by nearly a decade of average sea surface temperatures. Short-term winners are generally thermally tolerant encrusting and massive corals (Porites and faviids) and $<5 \mathrm{~cm}$ Acropora colonies. Ten years after the thermal disturbance, the community was still structurally different from its original composition and consisted of a combination of species that (1) were tolerant to stress, (2) survived as fragments and experienced rapid regrowth, and (3) were regionally persistent colonies that recruited locally

Our study has shown that although there was plenty of open space on the reefs in 1998, the thermally resistant massive Porites did not increase in absolute density and cover through time, and soft corals did not take over all the available space (Table 1). Long-term winners and losers differed from short-term winners and losers, although short-term winners were a subset of longer-term winners (Table 1, Fig. 5). Leptastrea and Goniastrea were short-term winners and locally dominant in 2010. Both of these species fragment easily by partial mortality. Goniastrea aspera can remain reproductive even after fragmenting into smaller colonies (Kai \& Sakai 2008). After spawning, the eggs that remain in $G$. aspera develop into brooding planulae, which have the capacity for short-distance dispersal (Sakai 1998). These traits may be partially responsible for the success of $G$. aspera on Sesoko Island, compared with the less common Favites chinensis colonies (Table 1), which revert back to immaturity upon fragmentation (Kai \& Sakai 2008).

\section{Return frequencies of thermal stress}

Barshis et al. (2010) showed that there were more heat-tolerant Porites lobata genotypes in a highly fluctuating environment than on the physically stable forereefs. Such results agree with those of McClanahan \& Maina (2003), who examined the coral response in
Kenya to natural temperature variance. Coral colonies in localities with naturally high temperature variance, on a daily basis, fared better under a regional temperature stress than colonies in localities with low daily variance. But are these responses simply a reflection of phenotypic plasticity or adaptations?

There is mounting evidence for adaptation under rapid environmental change (Endler 1986, Thompson 1998, Glynn et al. 2001, Berkelmans \& van Oppen 2006, Carroll et al. 2007, Maynard et al. 2008). Although studies have shown that reproduction is compromised after bleaching (Szmant \& Gassman 1990, Baird \& Marshall 2002), thermal stress events will continue to select for more thermally tolerant genotypes, as long as the corals remain sexually active. Sexual recombination alone, however, does not always increase population variability, as the more variable offspring generated by sexual recombination are not always favorable in the new environmental circumstances. Shorter periods between selection events might cause strong and persistent selective forcing. Therefore, ironically, the coral populations most evolutionarily responsive to climate change in the near future might occur in localities of high-frequency return periods. Long periods between thermal stress events (i.e. low-frequency return periods) will allow sexual recombination, but will also return the population to Hardy-Weinberg equilibrium, reducing overall fitness.

On a global scale, some regions have historically experienced either high ( 5 yr) or low ( 50 yr) return periods of thermal anomalies (Thompson \& van Woesik 2009). The same localities that experienced highreturn periods over the past several centuries have also recently, in the past $15 \mathrm{yr}$, experienced the greatest intensities of thermal stress. Sesoko Island and the surrounding region have historically experienced lowfrequency return periods of anomalous temperatures (Thompson \& van Woesik 2009) (Fig. 1). In the present study, the reef communities had 9 yr to recover. However, if subjected to more frequent thermal stresses, then, along with the differential survival of more thermally resistant corals (causing a further shift in species composition), there may be a shift in the sizefrequency distribution of Acropora towards smaller colonies. Again, within species of Acropora, small colonies are more tolerant to anomalous temperatures than large colonies (Loya et al. 2001, Nakamura \& van Woesik 2001, Bena \& van Woesik 2004), but the small colonies are sexually immature (Hall \& Hughes 1996). Therefore, if bleaching events do become more frequent, the shift toward small Acropora colonies will slow recruitment and recovery and will reduce population fitness. Certainly, in a rapidly changing climate, directional selection may be rapid (Thompson 1998, Schoener 2011), and adaptation of corals to climate 
change is most likely to take place in localities with high-frequency return periods of anomalous temperatures (Thompson \& van Woesik 2009).

\section{Projected changes}

The present study suggests that as the oceans warm even further, the coral assemblages will change. Reefs may soon essentially only support heat-tolerant coral species. The narrowing of genetic diversity within communities is likely to impact other dependent species such as fishes and crustaceans, especially if important reef-building branched corals, such as Acropora, Stylophora, Pocillopora and Porites cylindrica, become rare on account of their inherent sensitivity to thermal stress. Bleaching may also become punctuated over the next several decades. In the short term, the remnant yet hardy populations may show some resistance to the higher water temperatures, and bleaching may be reduced for a decade or more if Acropora and pocilloporids are removed from local reefs. However, reduced bleaching may give false hope because once the inevitable temperature threshold of the remnant communities is surpassed, widespread coral mortality will follow. Given that even the hardiest coral genera have their limits, global temperature increases will eventually lead to an exponential rate of local, regional and global reduction of coral species. To what extent this reduction of coral species will occur will depend on how rapidly and by how much the ocean temperatures increase, which depends on the fossil-fuel-emission pathway that humans choose.

Acknowledgements. We thank the Tropical Biosphere Research Center (TBRC), University of the Ryukyus, for providing a visiting professor fellowship to R.v.W. in the summer of 2010; the Japan Society for the Promotion of Science for providing a Fellowship to Y.L. in the summer of 2007; JSPS KAKENHI (C \& A) nos. 21570021 \& 21247006 for supporting K.S. We also thank the TBRC Director, Prof. H. Oku, for providing the opportunity and facilities to carry out the research. The assistance of the staff is greatly appreciated, especially that of S. Nakamura, Y. Nakano, A. Takemura, S. Harii and C. Uchima. We also extend thanks to T. Done and L. Devantier for sharing the Great Barrier Reef data. Our special thanks extend to S. van Woesik for editorial comments.

\section{LITERATURE CITED}

Aronson RB, Precht WF, MacIntyre IG, Murdoch TJT (2000) Coral bleach-out in Belize. Nature 405:36

Baird AH, Marshall PA (2002) Mortality, growth and reproduction in scleractinian corals following bleaching on the Great Barrier Reef. Mar Ecol Prog Ser 237:133-141

Baird AH, Bhagooli R, Ralph PJ, Takahashi S (2009) Coral bleaching: the role of the host. Trends Ecol Evol 24:16-20
Baker AC (2001) Corals' adaptive response to climate change. Nature 411:765-766

Barshis DJ, Stillman JH, Gates RD, Toonen RJ, Smith LW, Birkeland C (2010) Protein expression and genetic structure of the coral Porites lobata in an environmentally extreme Samoan back reef: Does host genotype limit phenotypic plasticity? Mol Ecol 19:1705-1720

Bena C, van Woesik R (2004) The impact of two bleaching events on the survival of small coral colonies (Okinawa, Japan). Bull Mar Sci 75:115-126

> Berkelmans R, van Oppen MJ (2006) The role of zooxanthellae in the thermal tolerance of corals: a 'nugget of hope' for coral reefs in an era of climate change. Proc R Soc Lond B 273:2305-2312

Bou-Abdallah F, Chasteen ND, Lesser MP (2006) Quenching of superoxide radicals by green fluorescent protein. Biochim Biophys Acta 1760:1690-1695

Brown BE, Suharsono (1990) Damage and recovery of coral reefs affected by El Niño related seawater warming in the thousand islands, Indonesia. Coral Reefs 8:163-170

Carroll SP, Hendry AP, Reznick DN, Fox CW (2007) Evolution on ecological time-scales. Funct Ecol 21:387-393

> Côté IM, Darling ES (2010) Rethinking ecosystem resilience in the face of climate change. PLoS Biol 8:e1000438

> Dayton PK (1971) Competition, disturbance and community organisation: the provision and subsequent utilisation of space in a rocky intertidal community. Ecol Monogr 41: 351-389

Done TJ, DeVantier LM, Turak E, Fisk DA, Wakeford M, van Woesik R (2010) Coral growth on three reefs: development of recovery benchmarks using a space for time approach. Coral Reefs 29:815-833

Donner SD, Skirving WJ, Little CM, Oppenheimer M, HoeghGuldberg O (2005) Global assessment of coral bleaching and required rates of adaptation under climate change. Glob Change Biol 11:2251-2265

Endler JA (1986) Natural selection in the wild. Princeton University Press, Princeton, NJ

> Fabricius KE (2006) Effects of irradiance, flow, and colony pigmentation on the temperature microenvironment around corals: Implications for coral bleaching? Limnol Oceanogr 51:30-37

Gates RD, Edmunds PJ (1999) The physiological mechanisms of acclimatization in tropical reef corals. Am Zool 39:30-43

Gelman A, Carlin J, Stern H, Rubin D (2003) Bayesian data analysis. Chapman \& Hall, New York, NY

Glynn PW (1984) Widespread coral mortality and the 1982-83 El Niño warming event. Environ Conserv 11:133-146

Glynn PW (1988) El Nino-Southern Oscillation 1982-1983: nearshore population, community, and ecosystem responses. Annu Rev Ecol Syst 19:309-345

> Glynn PW (1991) Coral reef bleaching in the 1980s and possible connections with global warming. Trends Ecol Evol 6:175-179

> Glynn PW (1993) Coral reef bleaching ecological perspectives. Coral Reefs 12:1-17

Glynn PW, Maté JL, Baker AC, Calderón MO (2001) Coral bleaching and mortality in Panama and Ecuador during the 1997-1998 El Niño-Southern Oscillation event: spatial/temporal patterns and comparisons with the 19821983 event. Bull Mar Sci 69:79-109

Golbuu Y, Victor S, Penland L, Idip D and others (2007) Palau's coral reefs show differential habitat recovery following the 1998-bleaching event. Coral Reefs 26:319-332

> Grottoli AG, Rodrigues LJ, Palardy JE (2006) Heterotrophic plasticity and resilience in bleached corals. Nature 440: 1186-1189 
Hall VR, Hughes TP (1996) Reproductive strategies of modular organisms: comparative studies of reef-building corals. Ecology 77:950-963

Hoegh-Guldberg O (1999) Climate change, coral bleaching and the future of the world's coral reefs. Mar Freshw Res 50:839-866

Hoegh-Guldberg O, Mumby PJ, Hooten AJ, Steneck RS and others (2007) Coral reefs under rapid climate change and ocean acidification. Science 318:1737-1742

Holling CS (1973) Resilience and stability of ecological systems. Annu Rev Ecol Syst 4:1-23

Hughes TP, Baird AH, Dinsdale EA, Moltschaniwskyj A, Prachett MS, Tanner JE, Willis BL (2000) Supply-side ecology works both ways: the link between benthic adults, fecundity, and larval recruits. Ecology 81:2241-2249

IPCC (Intergovernmental Panel on Climate Change) (2007) Climate change 2007: synthesis report. Contribution of Working Groups I, II and III to the Fourth Assessment Report of the Intergovernmental Panel on Climate Change. Core Writing Team, Pachauri RK, Reisinger A (eds). IPCC, Geneva, Switzerland

Kai S, Sakai K (2008) Effect of colony size and age on resource allocation between growth and reproduction in the corals Goniastrea aspera and Favites chinensis. Mar Ecol Prog Ser 354:133-139

Loya Y (1976) The Red Sea coral Stylophora pistillata is an $r$ strategist. Nature 259:478-480

Loya Y, Sakai K, Yamazato K, Nakano Y, Sambali H, van Woesik R (2001) Coral bleaching: the winners and the losers. Ecol Lett 4:122-131

MacArthur RH, Wilson EO (1967) The theory of island biogeography. Princeton University Press, Princeton, NJ

Marshall PA, Baird AH (2000) Bleaching of corals on the Great Barrier Reef: differential susceptibilities among taxa. Coral Reefs 19:155-163

Maynard JA, Anthony KRN, Marshall PA, Masiri I (2008) Major bleaching events can lead to increased thermal tolerance in corals. Mar Biol 155:173-182

McClanahan TR (2004) The relationship between bleaching and mortality of common corals. Mar Biol 144:1239-1245

- McClanahan TR, Maina J (2003) Response of coral assemblages to the interaction between natural temperature variation and rare warm-water events. Ecosystems 6: 551-563

McClanahan TR, Ateweberhan M, Muhando C, Maina J (2007a) Effects of climate and seawater temperature variation on coral bleaching and mortality. Ecol Monogr 77: 503-525

McClanahan TR, Ateweberhan M, Graham NAJ, Wilson SK, Sebastián CR, Guillaume MMM, Bruggemann JH (2007b) Western Indian Ocean coral communities: bleaching responses and susceptibility to extinction. Mar Ecol Prog Ser 337:1-13

Nakajima Y, Nishikawa A, Iguchi A, Sakai K (2010) Gene flow and genetic diversity of a broadcast-spawning coral in northern peripheral populations. PLoS ONE 5: e11149

Nakamura T, van Woesik R (2001) Water-flow rates and passive diffusion partially explain differential survival of corals during the 1998 bleaching event. Mar Ecol Prog Ser 212:301-304

Nakamura T, Yamasaki H, van Woesik R (2003) Water flow facilitates recovery from bleaching in the coral Stylophora pistillata. Mar Ecol Prog Ser 256:287-291

Nishikawa A, Katoh M, Sakai K (2003) Larval settlement rates and gene flow of broadcast-spawning (Acropora tenuis) and planula-brooding (Stylophora pistillata) corals. Mar Ecol Prog Ser 256:87-97

Papina M, Sakihama Y, Bena C, van Woesik R, Yamasaki H (2002) Separation of highly fluorescent proteins by SDSPAGE in Acroporidae corals. Comp Biochem Physiol 131: 767-774

Riegl B, Purkis S (2009) Model of coral population response to accelerated bleaching and mass mortality in a changing climate. Ecol Model 220:192-208

Roth L, Koksal S, van Woesik R (2010) Effects of thermal stress on key processes driving coral-population dynamics. Mar Ecol Prog Ser 411:73-87

> Rothman KJ (1990) No adjustments are needed for multiple comparisons. Epidemiology 1:43-46

> Sakai K (1998) Effect of colony size, polyp size, and budding mode on egg production in a colonial coral. Biol Bull 195: $319-325$

Sakai K, Yamazato K (1984) Coral recruitment to artificially denuded natural substrates on an Okinawan reef flat. Galaxea 3:57-69

Scheffer M, Carpenter SR (2003) Catastrophe regime shifts in ecosystems: linking theory to observation. Trends Ecol Evol 18:648-656

Schoener TW (2011) The newest synthesis: understanding the interplay of evolutionary and ecological dynamics. Science 331:426-429

> Smith-Keune C, van Oppen M (2006) Genetic structure of a reef-building coral from thermally distinct environments on the Great Barrier Reef. Coral Reefs 25:493-502

- Sousa WP (1979) Disturbance in marine intertidal boulder fields: the nonequilibrium maintenance of species diversity. Ecology 60:1225-1239

Szmant AM, Gassman NJ (1990) The effects of prolonged 'bleaching' on the tissue biomass and reproduction of the reef coral Montastrea annularis. Coral Reefs 8:217-224

Thompson JN (1998) Rapid evolution as an ecological process. Trends Ecol Evol 13:329-332

> Thompson DM, van Woesik R (2009) Corals escape bleaching in regions that recently and historically experienced frequent thermal stress. Proc R Soc Lond B 276:2893-2901

> van Nes EH, Scheffer M (2007) Slow recovery from perturbations as a generic indicator of a nearby catastrophic shift. Am Nat 169:738-747

van Woesik R, Done TJ (1997) Coral communities and reef growth in the southern Great Barrier Reef. Coral Reefs 16: 103-115

van Woesik R, Koksal S (2006) A coral population response (CPR) model for thermal stress. In: Phinney JT, HoeghGuldberg O, Kleypas J, Skirving W, Strong A (eds) Coral reefs and climate change: science and management. Coastal and Estuarine Studies 61. American Geophysical Union, Washington, DC, p 129-144

van Woesik R, Irikawa A, Loya Y (2004) Coral bleaching: signs of change in southern Japan. In: Rosenberg E, Loya Y (eds) Coral health and disease. Springer, Berlin, p 119-141

- Wallace CC (1985) Reproduction, recruitment and fragmentation in nine sympatric species of the coral genus Acropora. Mar Biol 88:217-233

Wilkinson C, Linden O, Cesar H, Hodgson G, Rubens J, Strong AE (1999) Ecological and socioeconomic impacts of 1998 coral mortality in the Indian Ocean: An ENSO impact and a warning of future change? Ambio 28:188-196

Zvuloni A, Artzy-Randrup Y, Stone L, van Woesik R, Loya Y (2008) Ecological size-frequency distributions: how to prevent and correct biases in spatial sampling. Limnol Oceanogr Methods 6:144-152

Submitted: January 26, 2011; Accepted: May 4, 2011

Proofs received from author(s): July 16, 2011 